\title{
Psychosocial Barriers of High School Students in English Class: A Case Study in Pongok Island
}

\author{
Haiyudi*, Sitthipon Art-in \\ Curriculum and Instruction Program, Faculty of Education, Khon Kaen University, Thailand
}

Received August 12, 2020; Revised September 1, 2020; Accepted October 19, 2020

\section{Cite This Paper in the following Citation Styles}

(a): [1] Haiyudi, Sitthipon Art-in, "Psychosocial Barriers of High School Students in English Class: A Case Study in Pongok Island," Universal Journal of Educational Research, Vol. 8, No. 11, pp. 5569 - 5575, 2020. DOI: 10.13189/ujer.2020.081160.

(b): Haiyudi, Sitthipon Art-in (2020). Psychosocial Barriers of High School Students in English Class: A Case Study in Pongok Island. Universal Journal of Educational Research, 8(11), 5569 - 5575. DOI: 10.13189/ujer.2020.081160.

Copyright $\mathrm{C} 2020$ by authors, all rights reserved. Authors agree that this article remains permanently open access under the terms of the Creative Commons Attribution License 4.0 International License

\begin{abstract}
Teaching and learning process belongs to a kind of two-way communication. Some noises or barriers usually appear during its process in the classroom. Psychosocial barrier is one of four popular barriers in communication. Thus, the purpose of this research is to identify the psychosocial barriers faced by high school students in English class. This research employs mixed-method using embedded design which consists of both quantitative as primary data and qualitative as supportive data. The population of this research consists of high school students in a rural area, in which Kepulauan Pongok was chosen as the case study sample. The sample was taken from 2 grades of two different high schools in Kepulauan Pongok, Southern Bangka Regency. In total, it consists of 50 students. The finding indicates a significant number of psychosocial barriers experienced by students especially in both field of experiences and filtering. Meanwhile, psychological distance is not quite significant. In detail, about $14.9 \%$ of those participants strongly agreed and $17 \%$ agreed that they face psychosocial barriers during learning English. The most impactful psychosocial barriers were English learning experiences in the previous class. Teachers' teaching styles are the riskiest barriers that cause the negative impacts of students' psychosocial in English class. Meanwhile, $36.2 \%$ stated a blue statement or were in a neutral position. As the rest felt like nothing happens about psychosocial barriers in English class. It is hoped that teachers can conduct the similar research in any subject to know and solve the psychosocial problems of students in order to adapt to the proper teaching method and counseling.
\end{abstract}

Keywords Psychosocial Barriers, Learning Process, Filtering, Field of Experiences

\section{Introduction}

\section{Rationale of the study}

Foreign language becomes special for Indonesian students, especially for those who are studying in rural area. One of its indicators is because they don't speak English in their daily life [7]. Learning access to technology is not as good as in a big city. On the other hand, the limited facility allows teachers not to be creative in teaching. Then, some barriers of learning may appear during English learning process in the classroom. Furthermore, the barriers in teaching and learning process often occur without any visible signal. Therefore, teachers need to find out the communication barriers in the class, so that the problems inside of the classroom can be easily handled. On the other hands, it is also to find ideal process of teaching and learning. However, teacher should be aware of communication barriers existing in the classroom due to some areas may be affected because of psychosocial barriers in communication.

As high school students, some are considered adequate to identify where they are, but some are hardly to determine where they are and what difficulties they faced in learning English. Normally, four communication barriers are often 
found in the classroom. Those four communication barriers have different ways of preventing as well as solving its problems. Psychosocial barrier is one out of those four barriers in communication. It becomes the most important barrier teacher must concern during teaching and learning process. It can be identified by collecting many areas of learning. Some communication theorists had divided these psychosocial barriers into several areas. In specific, some important aspects in psychological barriers associated by Antos [1] are fields of experiences where something related to background of someone such as needs and expectation. The second is filtering where someone's intention is caused by what we see and listen to. It is as the cause of ones' need and interest. The last one is psychological distance which related to the distance of the communication such as blocking and position where a communication happens.

On the other hands, a research in communication area, especially a classroom communication between teachers and students as well as students to students needs to be done. Some of teachers may just focus on improving teaching and learning aspect in the classroom, but never conduct a research about classroom communication especially breaking out its barriers. Whereas, the psychosocial barriers will affect the effectiveness of teaching strategies applied in the classroom. By identifying the barriers existing in in the classroom, teachers will be directed to find the proper teaching method easily.

Hence, the objective of this study is to identify the psychosocial barriers of students, especially in learning English. It is one of some barriers students often faced in the classroom. However, since barriers cannot be visually seen, a research is much needed. Teachers must have prior knowledge regarding to the effectiveness of teaching and learning process in the classroom. Therefore, by knowing psychosocial barriers of the students, teachers can easily adapt to the proper teaching technique and provide the counseling as needed. Teacher must look for the difficulties or barriers faced by students before starting the learning process. It is much better than having a late notice on students' psychosocial barriers. Again, in teaching and learning process, psychosocial barriers may not visually be seen. It automatically happens in the classroom as teachers or students don't really care of the way to get good communication. The most prominent things on this problem are to avoid and solve those communication barriers especially psychological barrier by adapting the proper technique on teaching and learning process.

\section{Communication}

Communication can be defined as the transmitting information process from someone to others [11]. On the other hands, Keyton [13] stated that communication is a process of transmitting information and common understanding from one to other. It is terminologically derived from Latin word communis which means common. Teaching and learning in the classroom becomes the model of real communication in a community. Once the students get the model of communication way through the teachers, it remains for a long time in the communication process among students and teacher. In fact, nobody can learn to communicate in a level of excellence without practicing and mastering the language. Some barriers will always appear on communication process. However, there are some popular barriers happening in communication process that communicators don't really pay attention to. They are famously called by process barrier, physical barrier, semantics barrier and psychosocial barrier.

The common communication that regularly happens consists of two ways. That is from sender to receiver and also feedback from receiver to the sender. However, the process of communication from sender to receiver is sometimes full of barriers or noises. On the other side, the purpose of communication is to get our message across clearly and ambiguously [3]. It means that the communication process requires effort from both sender and receiver to achieve the good level of communication. It is because the problem of the communication quality depends on one of this element. Keyton [13] stated that a problem in one of these elements will reduce the effectiveness of communication. Therefore, it is also called by communication barriers. In detail, Cheney [4] has figured out the communication process as explained in the following figure:

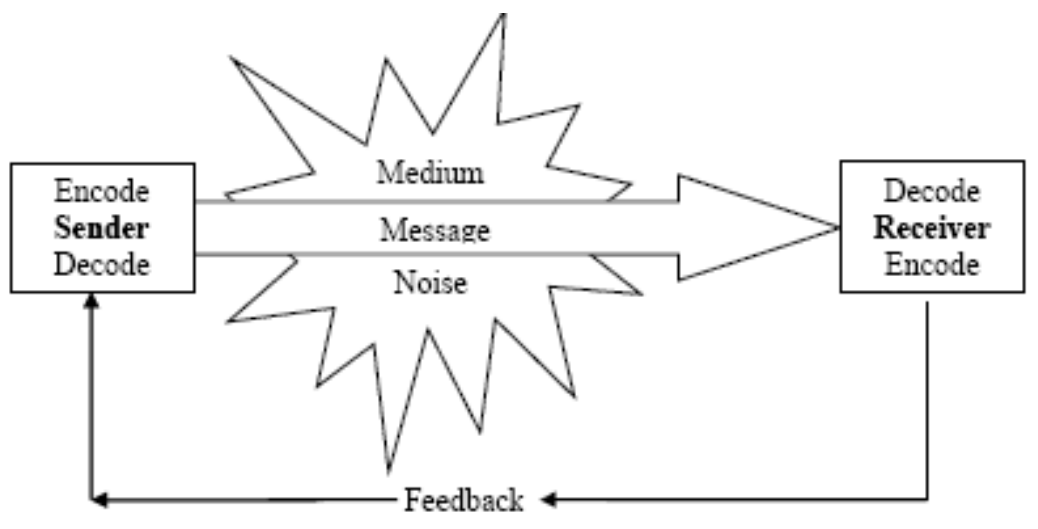

Figure 1. Communication process 
In an English class, teachers and students are acting as both senders and receivers. Then two-way communication will automatically happen and cannot be avoided. How teachers send a massage in a lesson will be influenced by some barriers. However, students will face a similar process in accepting the lesson from teachers. When students get unclear message, they will send an unclear message as the feedback to teachers or to other friends. Thus, it is essential for the teacher and students to know how to get the effective communication in the classroom in order to get an effective result of teaching and learning process. Besides, teacher may provide a proper method in teaching in order to reduce the level of communication barriers, especially psychosocial barriers.

Communication will not always run as well as hoped by both sender and receiver. Some communication barriers will occur on the process of transmitting the information. As Eisenberg [6] said that communication barriers can be divided into some types, such as process barrier, physical barrier, semantic barrier and also psychosocial barrier, this research will ony focus on identifying what psychological barriers are occuring in teaching and learning process of English class. This study will take a case study in Pongok Island, Southern Bangka regency, Indonesia.

\section{Psychosocial barriers}

Psychosocial is one out of several types of barriers in communication. The other three barriers are process barriers, physical barriers and semantic barriers. Those barriers have their own problems as well as solving ways [6]. They should get special and different treatments regarding to each barrier. Some communication theorists stated that some communication breakdowns often occur in the real life such as sincerity; empathy; self-perception; role-perception; effort to distort the message; images; vehicle for message; ability to communicate; listening ability; culture; tradition; conditioning; noise and feedback $[11,12,15]$.

Some important issues of this psychosocial barriers associated by Antos [1] are field of experience, filtering and psychological distance. (1) Field of experience: During communication process, the communicators need some other background information of the interlocutors or audience. It is to get effective communication. Communication process will be effective if the communicators have background understanding each other. However, it is undeniable that some problems in communication happen because of the low level of field of experiences in each communicator. Students' previous experiences about their English learning as well as different styles of teaching from different teachers are some specific causes that determine the level of risky experience. However, those kinds of important elements will influence how well the current English class will be. Furtherly, Sudjasmara [17] stated teaching styles hold a significant role in students learning motivation. (2) Filtering: Our own needs and interest will automatically guide us to do something happily. However, being interested on something will keep our eyes on it. In short, filtering means covering own learning motivation. The surrounding environment has a prominent role in uncover. On the other hands, if you are doing something unhappily, the filtering is automatically working on. It naturally happens without being realized. It can be caused by some elements that students' learning motivation is being spurred. However, it emotionally will be turned into what we like and are interested in. (3) Psychological distance: It happens between the people in which they are similar on the distance of physical. It includes the positon, blocking and also the distance of communication between those people. Some private conflicts among teacher to students or students to other students belong to this kind of barriers. However, these three areas of psychosocial barriers relate each other. Therefore, teachers must be aware of this barriers existing in teaching and learning process either in English class or other subjects.

\section{Methodology}

This research is classified into mixed-method research as the data are both in form of number and sentences to explain the result $[5,16]$. Furthermore, embedded design was adopted into this research. The main data are transformed into quantitative, while the qualitative data are just categorized as supportive data. This research was done in $2^{\text {nd }}$ semester of academic year 2019/2020 from March to May 2020. The objective of this study is to identify students learning experiences as well as psychosocial barriers during process of learning English in the classroom.

The populations of this research were divided into two group of students. They were grade 3 students of senior high school as familiarly known as Sekolah Menengah Atas (SMA) and grade 3 students of Junior High School known as Sekolah Menengah Pertama (SMP). All are located in the rural area, especially in Sub-district of Kelupauan Pongok, Southern Bangka Regency. Probability sampling is used in this research. Practically, Cluster Sampling was adopted to collect the data. It was about 25 grade 3 students at SMP and also 25 grade 3 students at SMA. Therefore, some steps of deciding the population were: a) determining the areas under Southern Bangka Regency; b) determining 3 most-considered rural areas under Southern Bangka Regency; c) choosing one sub-regency (Kepulauan Pongok) to be the population; d) determining the only 2 high schools to be sampling; e) taking one out of 2 classes (grade 3) which contains 25 students in each level to be participants of this research.

Data collecting process was done through questionnaire and survey. The quantitative data became the main data 
involved in this study, therefore, qualitative data will only complete and strengthen the numbers. Statistical Package for Social Science (SPSS) was employed in determining and analyzing the data in which the descriptive statistics would be badly needed.

\section{Result and Discussion}

\section{Finding}

\section{Validity and Reliability}

Item-Objective Congruence (IOC) was firstly conducted to get the acceptability of the questionnaire [19]. It involved some experts to validate the research instruments. There were 3 experts validating the questionnaires. Then after, the researcher could take the data based on the expert's viewpoints [14]. However, the validity of the questionnaire based on the participants' response is explained through the following table based on the comparison of t-table.

Table 1. Validity of the questionnaire

\begin{tabular}{cccc}
\hline No item & $\mathbf{r}_{x y}$ & $\mathbf{r}_{\text {table }}(\mathbf{4 7 )}$ & result \\
\hline 1 & - & 0.288 & - \\
\hline 2 & 0.339 & 0.288 & valid \\
\hline 3 & 0.298 & 0.288 & valid \\
\hline 4 & 0.421 & 0.288 & valid \\
\hline 5 & 0.696 & 0.288 & valid \\
\hline 6 & 0.537 & 0.288 & valid \\
\hline 7 & 0.634 & 0.288 & valid \\
\hline 8 & 0.667 & 0.288 & valid \\
\hline 9 & 0.621 & 0.288 & valid \\
\hline 10 & 0.530 & 0.288 & valid \\
\hline 11 & 0.622 & 0.288 & valid \\
\hline 12 & 0.476 & 0.288 & valid \\
\hline 13 & 0.610 & 0.288 & valid \\
\hline 14 & 0.479 & 0.288 & valid \\
\hline 15 & 0.415 & 0.288 & valid \\
\hline
\end{tabular}

On the other sides, the following table of Alpha Cronbach is also employed in determining the reliability of the respondent answer's as well as its consistency.

Table 2. the respondents' consistency

\begin{tabular}{ccc}
\hline Cronbach Alpha & N & Result \\
\hline .793 & 15 & Reliable \\
\hline
\end{tabular}

The table shows a reliable respondent' response. The value of .70 is the minimum value that the researcher should have for a useful rule of thumb $[18,19]$. It would be better if the score is preferably higher than .70. In this study, Alpha Cronbach shows 79 which is higher than .70. It indicates a good consistency and reliability.

Descriptive analysis of psychosocial barriers of students
Students' psychosocial barriers is divided into three sub-topics. They are field of experiences, filtering as well as psychological distance [1]. These following tables are presenting kinds of psychosocial barriers faced by students in the sub-regency of Kepulauan Pongok in detail:

Table 3. Field of experience in learning English

\begin{tabular}{cccccc}
\hline Field of experiences & SD & D & $\begin{array}{c}\text { N } \\
\text { \% }\end{array}$ & A & SA \\
\hline $\begin{array}{c}\text { I have studied English } \\
\text { before attending this level }\end{array}$ & 0 & 0 & 0 & 0 & 100 \\
\hline $\begin{array}{c}\text { I have mastered some } \\
\text { parts of English at the } \\
\text { previous level }\end{array}$ & 2.1 & 19.1 & 48.9 & 25.5 & 4 \\
\hline $\begin{array}{c}\text { I previously enjoyed } \\
\text { learning English with } \\
\text { teachers and used } \\
\text { techniques }\end{array}$ & 4.3 & 34 & 19.1 & 27.7 & 14.9 \\
\hline $\begin{array}{c}\text { I have an informal English } \\
\text { course before attending } \\
\text { this level }\end{array}$ & 14.9 & 25.5 & 27.7 & 23.4 & 8.5 \\
\hline $\begin{array}{c}\text { I was happy learning } \\
\text { English with the overall } \\
\text { environment }\end{array}$ & 17 & 3.9 & 19.1 & 25.5 & 6.4 \\
\hline
\end{tabular}

Table 3. Filtering in learning English

\begin{tabular}{cccccc}
\hline Filtering & SD & D & $\begin{array}{c}\text { N } \\
\text { \% }\end{array}$ & A & SA \\
\hline $\begin{array}{c}\text { I learn English based on } \\
\text { my own intention and } \\
\text { without any coercion }\end{array}$ & 2.1 & 6.4 & 10.6 & 31.9 & 48.9 \\
\hline $\begin{array}{c}\text { I totally understand that I } \\
\text { must learn English as it is } \\
\text { important for my next } \\
\text { career }\end{array}$ & 4.3 & 4.3 & 2.1 & 27.7 & 61.7 \\
\hline $\begin{array}{c}\text { I enjoy learning English in } \\
\text { my current level }\end{array}$ & 2.1 & 12.8 & 31.9 & 29.8 & 23.4 \\
\hline $\begin{array}{c}\text { I am happy with my } \\
\text { current teachers' teaching } \\
\text { style }\end{array}$ & 4.3 & 14.9 & 29.8 & 36.2 & 14.9 \\
\hline $\begin{array}{c}\text { I sometimes learn English } \\
\text { by myself either inside or } \\
\text { outside of the classroom }\end{array}$ & 2.1 & 8.5 & 48.9 & 25.5 & 14.9 \\
\hline
\end{tabular}

Table 3. Psychological distance in learning English

\begin{tabular}{cccccc}
\hline Psychological distance & SD & D & $\begin{array}{c}\text { N } \\
\text { \% }\end{array}$ & A & SA \\
\hline $\begin{array}{c}\text { I have a friendly } \\
\text { relationship with English } \\
\text { teacher either inside or } \\
\text { outside of the classroom }\end{array}$ & 2.1 & 10.6 & 8.5 & 38.3 & 40.4 \\
\hline $\begin{array}{c}\text { I always show my best in } \\
\text { English class }\end{array}$ & 2.1 & 6.4 & 44.7 & 25.5 & 21.3 \\
\hline $\begin{array}{c}\text { English is scheduled at the } \\
\text { proper time to learn }\end{array}$ & 0 & 27.6 & 23.4 & 31.9 & 17.0 \\
\hline $\begin{array}{c}\text { I feel free to ask anything } \\
\text { about English without } \\
\text { feeling reluctant }\end{array}$ & 2.1 & 12.8 & 19.1 & 34.0 & 31.9 \\
\hline $\begin{array}{c}\text { I have a good relationship } \\
\text { with friends so I feel } \\
\text { comfort to learn English }\end{array}$ & 4.3 & 0 & 4.3 & 23.4 & 68.1 \\
\hline & & & & & \\
\hline
\end{tabular}


Table 4. Overall frequency of psychosocial barriers

\begin{tabular}{|c|c|c|c|}
\hline Interval & mean & frequency & $\begin{array}{c}\text { Percentage } \\
(\%)\end{array}$ \\
\hline $39-45$ & 42 & 7 & 14.9 \\
\hline $46-52$ & 49 & 8 & 17.0 \\
\hline 53-59 & 56 & 17 & 36.2 \\
\hline $60-66$ & 63 & 11 & 23.4 \\
\hline $67-73$ & 70 & 4 & 8.5 \\
\hline \multicolumn{2}{|c|}{ Total } & 47 & 100.0 \\
\hline
\end{tabular}

\section{Case study}

Case study was employed to support those tables above. The case study was done by involving 4 participants consisting of 2 students of senior high school (SMA) and 2 students of junior high school (SMP). It was simultaneously conducted in a time. Before conducting the case study, the instrument has previously been validated by some experts in order to address the research objectives [16]. The questions are divided into three related topics regarding to psychosocial barriers as well. Those are field of experience, filtering and psychological distance. The interview was done together in each level of the students. Furtherly, it can be seen through the following script:

Field of experience:

"We have previously learnt English, but it was not a comprehensive study. We found some difficulties about understanding the lesson delivered by the previous teacher because she did not come to class for many times. We found it as the difficulty of learning English when we were in the previous level" (Student 1 and 2 of Junior High school).

"We've learned English since we were in junior high school, but we still feel as if we haven't got anything. Because sometimes the teacher didn't not come to the class. However, now we really need to learn English. We have to catch up English that has been left too far behind. The most unpleasant experience is about abundant assignments given by teacher. We sometimes are not enthusiastic to learn English" (Student 1 and 2 of Senior High School)

\section{Filtering:}

"In our current level, it has almost no difference to the previous one. Teacher did not come to the class for several times and it was always replaced by a piling assignment. The teacher taught in an unpleasant style, only explained but never taught us pleasantly. The teachers are often angry. (Student 1 and 2 of Junior High School)

"English in this level is almost the same as previous level. Because the teacher who teaches has nothing changed from previous level. There is no use of techniques and interesting media that makes the lesson seem to be ordinary. However, either we like it or not we have to study English independently. However, the spirit of learning English is well maintained because inevitably English is very important as a condition for any requirement purposes. (Student 1 and 2 of Senior High School)

Psychological distance:

"There has never been any dispute or private problem either to the teacher or classmates. Indeed, we encourage and help each other in learning English. The learning atmosphere is very comfortable. (Student 1 and 2 of Junior and Senior High School)

\section{Discussion}

In the explanation of the findings session, it can be seen several important points about the process of English learning in rural areas, case study in Kepulauan Pongok. All of the respondents had experiences in studying English before attending the current level. Thus, it can be clearly seen that the first type of those included psychosocial barriers, field of experience, is the most visible barrier occurring in teaching and learning English. From the statistical analysis designed through the interval approach that sets a minimum or lowest value as the strength of a psychosocial barriers finding, it can be seen that $14.9 \%$ of the data say that psychosocial barriers are strongly agreed to be found in English class which indicates a very influential barrier. Then, $17 \%$ also said to agree that psychosocial barriers are found in learning English. While $36.2 \%$ answered with a neutral statement which is indicated in a state of motion blur. Meanwhile $23.4 \%$ of the data indicate that there were no psychosocial obstacles in learning English. While, the last group of 8.5\% said there were no psychosocial obstacles in learning English at all.

Hence, it can be concluded that field of experience and filtering are types of barriers faced by the students in English classroom. While, psychological distance barriers are almost non-existent. In detail, the most prominent obstacle is related to the field of experiences of learning English such as teaching methods and teaching techniques used by the teachers in the previous level. This will indirectly affect the learning process at the current level. The same thing is also directly explained by the interviewee that some of the problems familiarly happened is about the teacher absence. The teachers often did not come the classroom for several reasons. This seems to be common in that local. It is because of another activity of teachers is not only teaching. As a result, the English ability of students is still left far behind. However, to solve those barriers, they also do independent learning to catch up on their backwardness. In the interview session, it is said that they are catching up through discussion and independent learning. Because inevitably, they have to learn, as the importance of English cannot be denied any more in the future. 
Meanwhile, in the type of filtering area, the interviewees indicate that barriers they previously faced in the past have been affecting self-limitation or motivation towards learning English. The descriptive data show that some students are not so enthusiastic in learning English because of the influence of the learning experience in the previous class. But that number was not so significant. However, another result, they limit themselves in accepting learning that is taking place at the current level.

While in other types namely psychological distance, there is almost no significant problem. Students do not have psychological problems either to the teacher or classmates so that the sense of comfort in learning English can still be maintained. Indeed, in the case study interview they said that their collaborative working to encourage the barriers faced as well as to help each other are quite good. Therefore, it illustrates that psychological distance does not become a significant barrier experienced by students in learning English. In short, students have a good relationship among friends and teachers either inside or outside of the school. It is something that should be appreciated.

In a learning process, which is not only English, teachers must find out the psychosocial barriers experienced by students. It is because of its effect on learning process will bring a barrier in term of communication barriers. By conducting a similar small research. it will capture intention and motivation in the latest learning process. In accordance with the hypothesis stated in the introduction that psychosocial barriers in the process of learning English will be unknown when nobody examines it. This is because these obstacles are invisible. However, the influence of learning motivation which is included in psychosocial, will affect how students' results and achievements in learning English.

\section{Conclusions}

Psychosocial barriers faced by students in the process of English learning were found. The most dominant type of the learning barriers which belong to psychosocial barriers is the process of previous learning. In the area of field of experience, it can be categorized as a less pleasant process of learning. In addition, students also limit themselves in the process of learning English. It is indirectly indicated as a result of experiences that were not so motivating the learning process known as filtering. Those two types of psychosocial barriers are dominantly emerging. Meanwhile, the barriers of psychological distance between teachers to students as well as students to other students do not become obstacles. Shortly, they have a good relationship either inside or outside the classroom.

Therefore, this study aims to open the teacher's insight that learning problems sometimes cannot be seen. However, communication barriers, especially psychosocial barriers often come without any signals. This often results in the emergence of ineffective communication between teachers and students, so that learning process does not go well. The process of delivering material that is not interesting is one of the causes of this barrier in the learning process. Therefore, before conducting a teaching and learning process, it is better for teachers to do this kind of small research to achieve effective communication. If the problem is known, the process of problem solving will be easier. As the learning process is an ongoing process, this kind of effort would be better done periodically.

Furthermore, it is very important for teachers to learn the types of psychosocial barriers that might occur in the classroom. Barriers that arise due to bad interactions will affect any learning process not only in English class. Hence, it is better for teachers to think about the communication process that exists while thinking about delivering the material. Because psychological problems will affect many things, including student motivation. In addition, the use of teaching methods and techniques that are fun is highly recommended in learning English especially in high school students. Since independent learning cannot be done optimally, guidance from the teacher is something that must be obtained. Shortly, if the teaching methods, approaches and teaching techniques are not attractive, this will be a barrier in the learning process.

\section{Acknowledgements}

Authors would like to express their gratitude to students of English Class of SMA and SMP in Pongok Island who cooperatively responded to the data collecting process of this research.

\section{REFERENCES}

[1] Antos, G. Handbook of interpersonal communication, Mouton De Gruyter, The Netherlands, 2011.

[2] Arthur, James., Waring, Michael., Coe, Robert, \& Hedges, Larry. V. Research Methods \& Methodologies in Education, SAGE Publication Ltd, London, 2012.

[3] Borisova, Lalka. Contemporary Problems of Corporate Communication, LAP LAMBERT Academic Publishing, Germany, 2013

[4] Cheney, G. Organizational communication in an age of globalization: Issues, reflections, practices, Waveland Press, Long Grove, 2011.

[5] Creswell, John W. Educational Research: Planning, Conducting, and Evaluating Quantitative and Qualitative Research-4th Ed, Pearson, Boston, 2012.

[6] Eisenberg, E. M. Organizational communication: Balancing creativity and constraint, Saint Martin's, New York, 2010. 
[7] Ellis, R. Second Language Acquisition, Oxford University Press, New York, 1997.

[8] Fraenkel, Jack R. How to Design and Evaluate Research in Education, McGraw-Hill Education, Singapore, 2016.

[9] Gay, L.R., Mills, Geoffrey. E., Airasian, Peter. Educational Research: Competencies for Analysis and Application, 9th Ed, Pearson. New Jersey, 2009.

[10] George, D. and Mallery, M. SPSS for Windows Step by Step: A Simple Guide and Reference, 17.0 Update, 10th Edition, Pearson, Boston, 2010.

[11] Giovannoni, Francesco, Xiong, Siyang. Communication under language barriers, Journal of Economic Theory, No.180, 247-303.

[12] Hartley BR, Hong C, Elowitz E. Communication in neurosurgery - the tower of Babel, World Neurosurg. No. $133,457-465$.

[13] Keyton, Joann. Communication Research: Asking Question, Finding Answers, MayfieldPub, USA, 2001
[14] Lam, K. W., Hassan, A., Sulaiman, T., \& Kamarudin, N. Evaluating the Face and Content Validity of an Instructional Technology Competency Instrument for University Lecturers in Malaysia. International Journal of Academic Research in Business and Social Sciences, Vol. 8, No. 5, 367-385.

[15] Lunenberg, F. C. Communication: The Process, Barriers and Improving Effectiveness. Schooling, Vol. 1, No, 1, 1-11.

[16] Raharjo, Mudjira. Studi Kasus dalam Penelitian Kualitatif: Konsep dan Prosedurnya, Unpublished Thesis. 2017.

[17] Sudjasmara, D. Bayuning. Teaching Style and Students' Motivation in Learning English as Foreign Language, Unpublished Thesis, 2018

[18] Tavakol, Mohsen., Dennick, Reg. Making sense of Cronbach's alpha, International Journal of Medical Education, Vol. 2, 53-55.

[19] Yamane, Taro. Statistics: An Introductory Analysis, 2nd Ed., Harper and Row, New York, 1967. 